Rafał Michałowski

Uniwersytet w Białymstoku e-mail: rafalm@uwb.edu.pl

\title{
Regulacja obrotu państwowymi gruntami rolnymi w świetle przepisów o reformie rolnej i osadnictwie na Ziemiach Odzyskanych
}

\author{
SUMMARY \\ Legal Regulation of Land Property Turnover in the Light of Decrees \\ on Land Reform and Settlement on Regained Territories
}

The decree of the Polish Comittee of National Liberation (PKWN) of 6th September 1944 on land reform and the decree of 6th September 1946 on the system of agriculture and settlement in the Regained Territories, are the most important legal acts that created Polish agrarian structure after the Second World War. The above-mentioned legal acts introduced the publiclaw model of property transfer for the land properties belonging to the State.

Both decrees regulated two complexes of legal activities: taking over land properties by the state and the distribution of state-owned land properties. The State has become the owner ex lege. Pursuant to both of these both decrees, the acquisition process of the state-owned land properties by individual farmers was divided into a few phases. Both procedures were based on administrative law instruments.

Key words: land reform, Regained Territories, agrarian structure, administrative decision 


\section{Uwagi wprowadzające}

Manifest Polskiego Komitetu Wyzwolenia Narodowego z 22 lipca 1944 r. ${ }^{1}$ zawierał zapowiedź przeprowadzenia szerokiej reformy rolnej, w założeniu mającej „przyśpieszyć odbudowę Kraju i zaspokoić odwieczny pęd chłopstwa polskiego do ziemi”. Była to zapowiedź wprowadzenia w prawodawstwie radykalnych środków służących przeistoczeniu ustroju rolnego w Polsce.

Dekret Polskiego Komitetu Wyzwolenia Narodowego z 6 września 1944 r. o przeprowadzeniu reformy rolnej ${ }^{2}$ oraz dekret Rady Ministrów z 6 września 1946 r. o ustroju rolnym i osadnictwie na obszarze Ziem Odzyskanych i byłego Wolnego Miasta Gdańska ${ }^{3}$ są aktami prawnymi, które w kardynalny sposób wpłynęły na ukształtowanie ustroju rolnego w Polsce po drugiej wojnie światowej. Jak się podkreśla, reforma rolna oparta była na wyraźnych przesłankach politycznych (dążeniu do likwidacji wielkiej własności ziemskiej) wypływających z założeń doktryny leninowskiej, natomiast osadnictwo na Ziemiach Odzyskanych to przedsięwzięcie, które zgodne było z oczekiwaniami całego społeczeństwa, bez względu na poglądy wiązane z daną warstwą społeczną ${ }^{4}$. Na stan państwowej własności rolniczej, obok wymienionych aktów prawnych, niewątpliwy wpływ miały również inne, takie jak dekret z 8 marca 1946 r. o majątkach opuszczonych i poniemieckich ${ }^{5}$, dekret z 5 września 1947 r. o przejściu na własność Państwa mienia pozostałego po osobach przesiedlonych do ZSRR ${ }^{6}$, dekret z 27 lipca 1949 r. o przejęciu na własność Państwa niepozostających w faktycznym władaniu właścicieli nieruchomości ziemskich położonych w niektórych powiatach województw: białostockiego, lubelskiego, rzeszowskiego i krakowskiego ${ }^{7}$ czy też ustawa z 20 marca 1950 r. o przejęciu przez Państwo dóbr martwej ręki, poręczeniu proboszczom posiadania gospodarstw rolnych i utworzeniu Funduszu Kościelnego ${ }^{8}$ W dalszej części artykułu przedstawione zostaną węzłowe zagadnienia związane z postanowieniami dekretu z 6 września 1944 r. oraz dekretu z 6 września 1946 r., z uwagi na wzmiankowaną doniosłość spo-

1 Manifest został opublikowany jako załącznik do Dziennika Ustaw $\mathrm{nr} 1 \mathrm{z}$ dnia 15 marca $1944 \mathrm{r}$.

2 Tekst jednolity Dz. U. z 1945 r. Nr 3, poz. 13 z późn. zm., powoływany dalej jako dekret z 6 września $1944 \mathrm{r}$.

3 Dz. U. Nr 49, poz. 279 z późn. zm., powoływany dalej jako dekret z 6 września $1946 \mathrm{r}$.

4 A. Stelmachowski, Kształtowanie sie rolnictwa $i$ prawa rolnego $w$ Polsce (rys historyczny), [w:] P. Czechowski, M. Korzycka-Iwanow, S. Prutis, A. Stelmachowski, Polskie prawo rolne na tle ustawodawstwa Unii Europejskiej, Warszawa 2002, s. 41.

5 Dz. U. Nr 13, poz. 87.

6 Dz. U. Nr 59, poz. 318 z późń. zm.; zgodnie z art. 5 ust. 3 dekretu, nieruchomości ziemskie, które przeszły na własność Państwa z mocy art. 1, włącza się do Państwowego Funduszu Ziemi.

7 Dz. U. Nr 46, poz. 339 z późń. zm.

8 Dz. U. Nr 9, poz. 87 z późn. zm. 
łeczną tych aktów prawnych, ale przede wszystkim ze względu na to, że właśnie one kształtowały charakterystyczny dla tego okresu model przenoszenia własności państwowych nieruchomości ziemskich.

Przeprowadzenie reformy rolnej wymagało dokonania różnorodnych czynności, które można podzielić na dwie grupy: zgromadzenie zasobu nieruchomości, a następnie ich rozdysponowanie ${ }^{9}$. Temu też schematowi odpowiadała akcja osadnicza na Ziemiach Zachodnich ${ }^{10}$. W związku z tym, w ten sposób uporządkowany został tok wywodów w niniejszym artykule.

\section{2. Źródła państwowej własności rolniczej}

Zgodnie z postanowieniami dekretu z 6 września 1944 r., na cele reformy rolnej zostały przejęte następujące kategorie nieruchomości ziemskich ${ }^{11}$ :

a) będące własnością obywateli Rzeszy Niemieckiej, nie-Polaków i obywateli polskich narodowości niemieckiej (art. 2 ust. 1 lit b). W wersji dekretu sprzed ogłoszenia tekstu jednolitego ten przepis wyróżniał dwie kategorie podmiotów: obywateli Rzeszy Niemieckiej nie-Polaków i obywateli polskich narodowości niemieckiej. Tekst jednolity wprowadził przecinek sugerujący, że mamy do czynienia z trzema różnymi przypadkami. Gdybyśmy wyróżnili osobną kategorię „nie-Polaków” okazałoby się, że znacząco wzrasta liczba osób pozbawionych własności nieruchomości. Niejasno też przedstawiałyby się relacje pomiędzy wyróżnionymi grupami podmiotów - zwłaszcza że kategoria „nie-Polaków” zdawałaby się pochłaniać pozostałe, zaś ze względu na niezwykle szeroki, a przy tym nieostry, zakres byłaby nieperatywna. Doktryna tamtego okresu stała na stanowisku, że mamy do czynienia z dwoma grupami osób pozbawionych własności ${ }^{12}$. Współcześnie Sąd Najwyższy w wyroku z 5 listopada 2002 r. ${ }^{13}$ doszedł do wniosku, że nie jest uzasadnione wyróżnienie trzech kategorii podmiotów na podstawie art. 2 ust. 1 lit. b), ponieważ tekst jednolity nie może odbiegać od tekstu oryginalnego. Uwzględniając współczesną aksjologię stwierdził (na tle pojęcia

9 Zob. W. Pawlak, Prawo rolne PRL, Warszawa - Poznań 1980, s. 39.

10 Por. H. Świątkowski, Prawo rolne, Warszawa 1966, s. 47.

11 Oprócz wskazanych kategorii nieruchomości, na cele reformy przeznaczone zostały także nieruchomości rolne stanowiące własność Skarbu Państwa z jakiegokolwiek tytułu (art. 2 ust. 1 lit. a) dekretu z 6 września 1944 r.).

12 F. Longchamps, Prawo agrarne, Warszawa 1949, s. 89 (taki wniosek można wywieść z rozważań autora); J. Paliwoda, Przebudowa ustroju rolnego. Zakres działania administracji rolnej, Warszawa 1964, s. 37; H. Świątkowski, op. cit., s. 49.

13 III CKN 273/01, „Lex” nr 77039. 
„obywatel polski narodowości niemieckiej”), że obywatel polski, który zgłosił przynależność do narodowości niemieckiej bez istotnego przymusu, przez wzgląd na otrzymanie przywilejów, dał tym samym wyraz braku przynależności do narodu polskiego;

b) będące własnością osób skazanych prawomocnie za zdradę stanu, za dezercję lub uchylanie się od służby wojskowej, za pomoc udzieloną okupantom ze szkodą dla Państwa lub miejscowej ludności, względnie za inne przestępstwa, przewidziane w dekrecie Polskiego Komitetu Wyzwolenia Narodowego z 31 sierpnia 1944 r. o wymiarze kary dla faszystowsko-hitlerowskich zbrodniarzy winnych zabójstw i znęcania się nad ludnością cywilną i jeńcami oraz dla zdrajców Narodu Polskiego ${ }^{14}$ oraz w dekrecie Polskiego Komitetu Wyzwolenia Narodowego z dnia 30 października 1944 r. o ochronie Państwa ${ }^{15}$ (art. 2 ust. 1 lit. c). Ostatni z wymienionych aktów prawnych został uchylony przez art. 40 pkt 1 dekretu z 16 listopada 1945 r. o przestępstwach szczególnie niebezpiecznych w okresie odbudowy Państwa ${ }^{16}$ (pierwsza wersja tzw. małego kodeksu karnego);

c) skonfiskowane $\mathrm{z}$ jakichkolwiek innych prawnych przyczyn (art. 2 ust. 1 lit. d). Zdarzeniem podpadającym pod zakres wyznaczony tym przepisem było w szczególności orzeczenie konfiskaty majątku jako kary dodatkowej albo przejście majątku na własność Skarbu Państwa w wyniku innego orzeczenia, przykładowo na podstawie art. $13 \$ 2$ dekretu z 28 czerwca 1946 r. o odpowiedzialności karnej za odstępstwo od narodowości polskiej w czasie wojny $1939-1945 \mathrm{r}^{17}$;

d) stanowiące własność albo współwłasność osób fizycznych lub prawnych, jeżeli ich rozmiar łączny przekraczał bądź 100 ha powierzchni ogólnej, bądź 50 ha użytków rolnych, a na terenie województw poznańskiego, pomorskiego i śląskiego, jeśli ich rozmiar łączny przekraczał 100 ha powierzchni ogólnej, niezależnie od wielkości użytków rolnych tej powierzchni (art. 2 ust. 1 lit. e). W doktrynie zarysowała się rozbieżność stanowisk w kwestii, czy ów przepis działał permanentnie i w każdym przypadku mającym miejsce po dniu jego wejścia w życie, tj. po 13 września 1944 r., gdy dany podmiot stał się właścicielem nieruchomości ziemskich przekraczających wskazane tam

14 Dz. U. Nr 4, poz. 16 z późn. zm.

15 Dz. U. Nr 10, poz. 50.

16 Dz. U. Nr 53, poz. 300.

17 Dz. U. Nr 46, poz. 237 z późn. zm.; przykład zaczerpnięty z: F. Longchamps, op. cit., s. 46-47. 
maksima obszarowe, przechodziły one na własność Skarbu Państwa ${ }^{18}$ czy ów skutek miał charakter jednorazowy i nastąpił tylko $\mathrm{w}$ dniu wejścia w życie dekretu ${ }^{19}$. Obecnie nie budzi wątpliwości, że poprawne jest to drugie rozwiązanie, za słusznością którego opowiedział się Trybunał Konstytucyjny w uchwale z 16 kwietnia 1996 r. ${ }^{20}$ Trybunał w uzasadnieniu stwierdził, że gdyby normodawca chciał ukierunkować działanie mechanizmu omawianego przepisu na przyszłość, to winien albo go inaczej sformułować, albo dodać inny, wyraźnie przewidujący taki skutek.

Wszystkie te nieruchomości przeszły na własność Skarbu Państwa bezzwłocznie, bez odszkodowania (art. 2 ust. 1 in fine) wolne od obciążeń. Mieliśmy tu do czynienia z pierwotnym nabyciem własności ex lege ${ }^{21}$. Jest to dobitny przykład radykalności przyjętych przez prawodawcę rozwiązań, realizującego rewolucyjne przeobrażenia struktury własnościowej polskiego rolnictwa.

Wyjaśnienia wymaga pojęcie „nieruchomości ziemskiej”, co ma pierwszorzędne znaczenie przy określeniu zakresu oddziaływania norm dekretu z 6 września $1944 \mathrm{r}^{22}$ Franciszek Longchamps stwierdził, że dekret z 6 września 1944 r. pozostawia otwartą sprawę interpretacji tego określenia, jedynie z art. 2 ust. 1 lit. e) wynikało, że „nieruchomości ziemskie” są zakresowo obszerniejsze niż „użytki rolne” ${ }^{23}$. Józef Paliwoda ograniczył się do stwierdzenia, że pojęcie „nieruchomość rolna”, zawarte w ustawie z 13 lipca 1957 r. o obrocie nieruchomościami rolnymi ${ }^{24}$, zastąpiło, jego zdaniem, niezadowalające, a używane w przepisach o reformie rolnej i osadnictwie pojęcie „nieruchomości ziemskiej” (przeciwstawione „nieruchomościom miejskim” ${ }^{25}$. Według H. Świątkowskiego ustawodawstwo odnoszące się do osadnictwa i reformy rolnej pozostawiało otwartą kwestię wypełnienia odpowiednią treścią pojęcia „nieruchomości ziemskiej”. Zwracał uwagę, że zostało ono użyte w opozycji do pojęcia „nieruchomości miejskiej”.

18 Zob. J. Paliwoda, op. cit., s. 39 oraz s. 80 przyp. 73, podając, że takie rozwiązanie przyjęła praktyka; por. też: W. Bendetson, H. Świątkowski, Rola prawa w umocnieniu sojuszu robotniczo-chłopskiego, [w:] Zagadnienia prawne rolnictwa. Materialy konferencji naukowej 5-7 grudnia 1955 r., red. S. Szera, Warszawa 1956, s. 10, gdzie o maksymalnych pułapach obszarowych przyjętych w dekrecie z 6 września 1944 r. pisze się jako o wyznaczających „maksimum indywidualnego władania ziemią - własności kułackiej”.

19 F. Longchamps, op. cit., s. 48; W. Pawlak, Z zagadnień prawnych reformy rolnej w Polsce Ludowej, RPEiS 1958, nr 2, passim; H. Świątkowski, op. cit., s. 50.

20 W 15/95, OTK 1996, nr 2, poz. 13.

21 F. Longchamps, op. cit., s. 48, H. Świątkowski, op. cit., s. 50.

22 O stanowisku, które zajmowało w tej kwestii Ministerstwo Rolnictwa zob. A. Machnikowska, Prawo własności w Polsce w Latach 1944-1981. Studium historycznoprawne, Gdańsk 2010, s. 190.

23 F. Longchamps, op. cit., s. 45.

24 Dz. U. Nr 39, poz. 172, z późn. zm.

25 J. Paliwoda, op. cit., s. 17. 
Nieruchomościami ziemskimi były jego zdaniem nieruchomości użytkowane na cele rolnicze $\mathrm{w}$ szerokim znaczeniu, obejmując swym zakresem nie tylko grunty wykorzystywane bezpośrednio do produkcji rolnej, ale również i te, bez których produkcja nie byłaby możliwa (przykładowo: grunty pod budynkami, okólniki, drogi wewnętrzne, podwórza). W odróżnieniu od desygnatów nazwy „nieruchomośćc w rozumieniu art. 46 Kodeksu cywilnego ${ }^{26}$, desygnaty nazwy „nieruchomość ziemska” mogły składać się nawet z kilkunastu nieruchomości $\mathrm{w}$ rozumieniu kodeksowym ${ }^{27}$. Niezwykle istotne znaczenie praktyczne należy przypisać wykładni dokonanej przez Trybunał Konstytucyjny w uchwale z 19 września $1990 \mathrm{r}^{28}$ Trybunał stwierdził, że ustawodawca pod pojęciem „nieruchomości ziemskiej” miał na względzie obiekty mienia nieruchomego, które są lub mogą być wykorzystane do prowadzenia działalności wytwórczej w rolnictwie w zakresie produkcji roślinnej, zwierzęcej i sadowniczej. Ów wniosek znajduje uzasadnienie w tytule dekretu z 6 września 1946 r., jak i w treści niektórych jego przepisów (art. 1 ust. 2 lit. „a” i „b”, czy też art. 6). Aleksander Lichorowicz krytycznie ustosunkował się do konkluzji i prowadzących do niej wywodów zawartych w tej uchwale. Jego zdaniem rekonstruując pojęcie „nieruchomości ziemskiej” dla potrzeb dekretu z 6 września 1944 r. należy sięgnąć do przepisów wykonawczych Ministra Sprawiedliwości i Prezesa Głównego Urzędu Ziemskiego z 12 września 1919 r. w sprawie stosowania rozporządzenia tymczasowego Rady Ministrów z 1 września 1919 r ${ }^{29}$, normującego przenoszenie własności nieruchomości ziemskich. Zgodnie z nimi, za nieruchomości ziemskie należało uważać nieruchomości położone poza obrębem miast, przy czym nieruchomości znajdujące się w posiadaniu drobnych rolników, działki letniskowe, wille podmiejskie, kolonie robotnicze i urzędnicze, mimo że znajdowały się poza obrębem miast, nie miały statusu nieruchomości ziemskich ${ }^{30}$. Autor uznaje jednak możliwość przyjęcia na płaszczyźnie dogmatycznej wniosków wynikających z uchwały Trybunału Konstytucyjnego, o ile uzna się, że przepisy wykonawcze z 12 września 1919 r. nie miały powszechnie obowiązującej mocy, gdyż nie zostały opublikowane w Dzienniku Ustaw ${ }^{31}$. W tej sytuacji dopuszczalne byłoby

26 Ustawa z 23 kwietnia 1964 r. Kodeks cywilny (Dz. U. Nr 16, poz. 93 z późn. zm.).

27 H. Świątkowski, op. cit., s. 48-49, przyp. 2.

28 W 3/89, OTK 1990, nr 1 poz. 26. Zob. również wyrok WSA w Warszawie z 6 października 2009 r. IV SA/Wa 1165/09 (Lex nr 574127) i przywołane w treści uzasadnienia orzecznictwo; por. też wyrok SN z dnia 17 lutego 2010 r., IV CSK 345/09 (Lex nr 577697).

29 M. P. Nr 206, s. 1; przepisy wydano do rozporządzenia tymczasowego Rady Ministrów z 12 września 1919 r. normującego przenoszenie własności nieruchomości ziemskich (Dz. U. Nr 73, poz. 428 z późn. zm.).

30 A. Lichorowicz, Pojęcie nieruchomości ziemskiej w orzecznictwie Trybunału Konstytucyjnego i Naczelnego Sadu Administracyjnego, [w:] Rozprawy prawnicze. Ksiegga pamiątkowa Profesora Maksymiliana Pazdana, Zakamycze, Kraków 2005, s. 1088.

31 Zob. powoływane przez A. Lichorowicza orzeczenie Sądu Najwyższego z 2 października 1922 r., I C 174/22, Orz. SN 1922, poz. 82. 
kształtowanie przez Trybunał pojęcia „nieruchomość ziemska”, zwłaszcza jeśli ma to praktyczną doniosłośćs ${ }^{32}$. W doktrynie pojawił się również pogląd, że nazwie „nieruchomość ziemska” należy nadawać znaczenie wynikające ze wskazanego rozporządzenia z 1 września 1919 r., interpretowanego przez pryzmat przepisów ustawy z dnia 15 lipca 1920 r. o reformie rolnej ${ }^{33}$. Autor tej koncepcji, Ł. Bielecki, ostatecznie doszedł do wniosku, że nieruchomości ziemskie to grunty, mające przez swą specyfikę lub przeznaczenie charakter typowo „wiejski”" Nie były to jedynie nieruchomości rolne, ale grunty mające szeroko pojęty związek z produkcją rolną lub leśną. Jednak, biorąc pod uwagę cele dekretu z 6 września 1944 r. sformułowane w art. 2, autor dochodzi do wniosku, że zakresem oddziaływania norm tego aktu prawnego objęte zostały jedynie nieruchomości ziemskie o charakterze stricte rolniczym ${ }^{35}$.

W celu przebudowy ustroju rolnego powołano do życia Państwowy Fundusz Ziemi (art. 3 ust. 1 dekretu z 6 września 1944 r.). Miał on być, w pierwotnych zamierzeniach normodawcy, kontynuacją przedwojennego Funduszu Obrotowego Reformy Rolnej ${ }^{36}$. Jego powstanie było ściśle powiązane z koncepcją reformy rolnej, został utworzony dla realizacji jej celów ${ }^{37}$. W skład Funduszu, obok innych składników wskazanych w art. 3 ust. 2, weszły nieruchomości ziemskie, o których mowa w art. 2 ust. 1 dekretu z 6 września 1944 r. Państwowy Fundusz Ziemi określany był $\mathrm{w}$ piśmiennictwie prawniczym jako wyodrębniona masa majątkowa przeznaczona do przebudowy ustroju rolnego ${ }^{38}$. Trzeba nadmienić,

32 A. Lichorowicz, op. cit., s. 1092-1093. Trudno jednak zgodzić się z kwalifikacją w tym kontekście definicji nieruchomości ziemskiej jako nieposiadającej charakteru iuris cogentis, co czyni A. Lichorowicz. Wszak już sam podział na przepisy imperatywne i dyspozytywne jest czymś innym niż kwalifikacja przepisu jako powszechne obowiązujący czy też pozbawiony takiej cechy. Dopiero w odniesieniu do przepisów powszechnie obowiązujących można odnieść podział na imperatywne i dyspozytywne w zależności od tego, czy zastosowanie dyspozycji norm zrekonstruowanych z tychże przepisów może zostać wyłączone z woli strony stosunku prawnego, w ramach którego zachowanie nakazywane przez daną normę miałoby być zrealizowane.

33 Dz. U. Nr 70, poz. 462.

34 Ł. Bielecki, Nacjonalizacja nieruchomości ziemskich na obszarze południowo-wschodniego pogranicza Polski (część I), „Rejent” 2007, nr 5, s. 20.

35 Ibidem, s. 28; zob. też: W. Ziętek, W sprawie pojęcia nieruchomości ziemskiej, „Rejent” 2008, nr 4, s. 142-146. Autor, odnosząc się do poglądów Ł. Bieleckiego, krytykuje prezentowany przez niego sposób rozumienia pojęcia „nieruchomość ziemska” na gruncie dekretu z 6 września 1944 r. Polemika ta nie wydaje się jednak w pełni przekonująca, gdyż Ł. Bielecki nie formułuje opinii (co mu przypisuje W. Ziętek), że dekret z 6 września 1944 r. dotyczył wszystkich nieruchomości ziemskich w rozumieniu rozporządzenia z 1 września $1919 \mathrm{r}$.

36 A. Zieliński, Formy prawne gospodarowania nieruchomościami Państwowego Funduszu Ziemi, Poznań 1980, s. 13.

37 Ibidem, s. 12.

38 Por. F. Longchamps, op. cit., s. 56; H. Świątkowski, op. cit., s. 47; J. Paliwoda, op. cit., s. 21; W. Pawlak, op. cit., s. 180. Wyczerpująco charakter prawny Państwowego Funduszu Ziemi analizuje A. Zieliński; zob. tegoż, op. cit., s. 33-42. 
że od momentu uchwalenia ustawy budżetowej na $1951 \mathrm{r}^{39}$ jedynym składnikiem PFZ były nieruchomości, natomiast inne składniki mienia wchodzące dotychczas do niego, stały się dochodem budżetów terenowych ${ }^{40}$.

Z kolei dekret z 6 września 1946 r. w art. 1 ust. 1 postanowił, że na cele tam wymienione przeznaczone zostały wszelkie nieruchomości ziemskie, z wyjątkiem będących własnością osób fizycznych. Nieruchomości te tworzyły zapas ziemi (art. 1 ust. 2). Do zapasu ziemi mogły też być, jak stanowił art. 2 ust. 1 dekretu z 6 września 1946 r., włączone nieruchomości położone $\mathrm{w}$ granicach administracyjnych miast, $\mathrm{z}$ wyjątkiem będących własnością osób fizycznych. Również niektóre kategorie gruntów leśnych zasiliły zapas nieruchomości (zob. art. 3 ust. 1). Nieruchomości znajdujące się w zapasie ziemi weszły w skład Państwowego Funduszu Ziemi (zdanie drugie art. 4 dekretu z 6 września 1946 r.). Wskazane nieruchomości przeszły na własność Państwa, o ile jeszcze nią nie były (art. 4 , zdanie pierwsze). Ustalając, jakie nieruchomości weszły do zapasu ziemi, w szczególności trzeba wskazać, że jeszcze przed uchwaleniem dekretu z 6 września 1946 r., art. 4 dekretu z 13 listopada 1945 r. o zarządzie Ziem Odzyskanych ${ }^{41}$ rozciągnął na Ziemie Odzyskane ustawodawstwo obowiązujące na obszarze Sądu Okręgowego w Poznaniu. Data jego wejścia w życie (zgodnie z art. 10 wszedł on w życie z dniem ogłoszenia) była jednocześnie datą rozciągnięcia na Ziemie Zachodnie przepisów dekretu z 6 września 1944 r. Wówczas więc własnością Skarbu Państwa stały się m.in. nieruchomości wskazane w art. 2 ust. 1 lit. b) oraz e) powyższego dekretu. Także dekret z 8 marca 1946 r. o majątkach opuszczonych i poniemieckich stanowił podstawę przejścia na własność Skarbu Państwa określonych kategorii mienia, również nieruchomości ziemskich (zob. art. 2 dekretu). Tak więc, na mocy postanowień dekretu z 6 września 1944 r., na Skarb Państwa przeszła własność niektórych nieruchomości ziemskich, które nie stały się jego własnością na mocy wcześniejszych aktów prawnych; przykładowo, chodziło o nieruchomości ziemskie będące własnością związków samorządu terytorialnego ${ }^{42}$.

39 Dz. U. z 1951 r. Nr 18, poz. 145.

40 Szczegółowo: A. Zieliński, op. cit., s. 24-25.

41 Dz. U. Nr 51, poz. 295, z późn. zm.

42 F. Longchamps, op. cit., s. 94; zob. też okólnik Ministra Ziem Odzyskanych Nr 38/48 z 28 lipca 1948 r. w sprawie majątku byłych niemieckich gmin na obszarze Ziem Odzyskanych (Dz. Urz. MZO Nr 14, poz. 131). 


\section{Dysponowanie państwowymi nieruchomościami rolnymi}

\subsection{Regulacja dekretu o przeprowadzeniu reformy rolnej}

Nieruchomości ziemskie przejęte w trybie przepisów dekretu z 6 września 1944 r. miały zostać przeznaczone m.in. na powiększenie gospodarstw karłowatych, małorolnych i średniorolnych (art. 2 ust. 2 lit. a) oraz na tworzenie nowych samodzielnych gospodarstw rolnych dla bezrolnych, robotników i pracowników rolnych oraz drobnych dzierżawców (art. 2 ust 2 lit. b). Dekret nie określał podstaw wyróżnienia poszczególnych rodzajów gospodarstw uprawnionych do skorzystania z parcelacji, prawodawca uczynił to $\mathrm{w}$ rozporządzeniu Ministra Rolnictwa i Reform Rolnych z 1 marca 1945 r. w sprawie wykonaniu dekretu Polskiego Komitetu Wyzwolenia Narodowego z 6 września 1944 r. o wykonaniu reformy rolnej ${ }^{43}$. Zgodnie z brzmieniem $\$ 2$ rozporządzenia, obszar gospodarstw karłowatych nie przekraczał 2 ha, gospodarstwa małorolne miały obszar od 2 do $5 \mathrm{ha}$, natomiast średniorolne - od 5 do $10 \mathrm{ha}^{44}, \mathrm{z}$ tym że posiadacze gospodarstw $\mathrm{z}$ ostatniej grupy uczestniczyli w parcelacji, o ile byli obarczeni liczną rodziną. Rozporządzenie określiło również, że bezrolni, robotnicy rolni oraz dzierżawcy mogli skorzystać z reformy rolnej, jeśli prowadzili własne gospodarstwo domowe, o ile praca na roli stanowiła dla nich zawód dający główne źródło utrzymania (\$3). Dekret wprowadzał dla gospodarstw nowo utworzonych maksymalną normę obszarową 5 ha ziemi średniej jakości, dla gospodarstw ogrodniczo-warzywnych zaś 2 ha (art. 12 ust. 2). Ów zapis należało rozpatrywać wespół z ust. 1 art. 13, zgodnie z którym obszar nowo utworzonych gospodarstw, jak również obszar, do którego mają być powiększone gospodarstwa karłowate, małorolne i średniorolne, powinien być uzależniony od jakości gleby i stosunku miejscowego zapotrzebowania ziemi do będącego do dyspozycji zapasu ziemi.

Jednakże trzeba zauważyć, że zgodnie z pierwotnym brzmieniem art. 13 ust. 1 dekretu z 6 września $1944 \mathrm{r}^{45}$, obszar nowo utworzonych gospodarstw, jak również obszar, do którego mają być powiększone gospodarstwa karłowate, powinien być uzależniony od jakości gleby i stosunku miejscowego zapotrzebowania ziemi do będącego do dyspozycji zapasu ziemi. Z kolei $\$ 2$ art. 13 stanowił, że obszar ten dla gospodarstw nowo utworzonych w zasadzie nie mógł wynosić więcej niż 5 ha ziemi średniej jakości, a dla gospodarstw ogrodniczo-warzywnych nie mógł przekraczać 2 ha, dla parcel rzemieślniczo-wiejskich nie mógł przekraczać

43 Dz. U. Nr 10, poz. 50, z późn. zm.

44 Na marginesie można też wskazać, że prawodawca wprowadzając przesłanki podziału gospodarstw na poszczególne kategorie nie ustrzegł się podręcznikowego (nie jedynego zresztą) błędu, a przynajmniej nieścisłości. Nie może być tak, że górnym pułapem gospodarstw małorolnych jest norma 5 ha, będąca jednocześnie dolną normą gospodarstw średniorolnych. Oczywiście (nie ma zresztą innej drogi) należy tę nieścisłość wyeliminować w drodze wykładni, por. Z. Ziembiński, Logika praktyczna, Warszawa 2002, s. 59.

45 Dz. U. Nr 4, poz. 17. 
2 ha, a dla parcel robotniczych itp. 1/4 ha. Takie rozwiązanie korespondowało $\mathrm{z}$ art. 2 ust. 2 lit. a) ib), mówiącymi o celach reformy, którymi miały być upełnorolnienie istniejących gospodarstw o powierzchni poniżej pięciu hektarów użytków rolnych oraz tworzenie nowych samodzielnych gospodarstw rolnych dla bezrolnych, robotników i pracowników rolnych oraz drobnych dzierżawców. Inaczej więc niż to zapowiadał Manifest PKWN z 22 lipca 1944 r., wymieniając w dekrecie podmioty uprawnione do uczestnictwa w parcelacji, prawodawca pominął tam gospodarstwa średniorolne obarczone liczną rodziną. W instrukcji Resortu Rolnictwa i Reform Rolnych z 11 października 1944 r. o przyśpieszonym trybie wykonania reformy rolnej ${ }^{46} \mathrm{w}$ art. 12 wskazano jako uprawnionych do skorzystania z parcelacji „W uzupełnieniu postanowień dekretu z 6 września $1944 \mathrm{r}$. i zgodzie z Manifestem PKWN z 22 lipca 1944 r. także chłopów - właścicieli gospodarstw poniżej 10 ha, obarczonych liczną rodziną". Oceniając ten stan rzeczy z dzisiejszej perspektywy, z przyczyn oczywistych nie można uznać postanowień instrukcji za źródło prawa. Wówczas takie „niuanse” nie były brane pod uwagę a w praktyce instrukcja służyła za podstawę do nadawania ziemi chłopom średniorolnym do czasu nowelizacji dekretu z 6 września 1944 r. oraz wydania rozporządzenia wykonawczego z 1 marca $1945 \mathrm{rr}^{47}$ Jest to jednak kolejny przykład realizacji fundamentalnych przemian $\mathrm{w}$ rolnictwie wszelkimi dostępnymi metodami.

W przypadku gdyby zapas ziemi nie starczył na obdzielenie wszystkich uprawnionych do normy 5 ha, to zgodnie z $\$ 28$ lit. a) oraz b) instrukcji Ministra Rolnictwa i Reform Rolnych z 1 marca 1945 r. o wykonaniu reformy rolnej ${ }^{48}$ należało uzupełniać możliwie najwięcej gospodarstw do 5 ha, a pozostałe gospodarstwa nienadzielone wraz z bezrolnymi miały prawo ubiegać się o ziemię w zachodnich i północnych województwach. Postanowienia te nie zostały jednak faktycznie zrealizowane przy przeprowadzaniu reformy rolnej, czego dowodem był okólnik Ministerstwa Rolnictwa i Reform Rolnych z 24 stycznia 1946 r. w sprawnie realizacji $\$ 28$ instrukcji z 1 marca 1945 r. o wykonaniu reformy rolnej ${ }^{49}$ stwierdzający wprost, że postanowienia $\$ 28$ instrukcji nie były realizowane i nakazujący, aby tam, gdzie to jeszcze możliwe, „przepis ten w całej rozciągłości ściśle był wykonywany" ${ }^{50}$.

46 Opublikowana w zbiorze: Reforma rolna PKWN. Materiały i dokumenty, Warszawa 1959, s. 39-45.

47 Zob. W. Bendetson, H. Świątkowski, op. cit., s. 11. Na fakt, że instrukcje oraz okólniki wiążą władze, ale nie obywateli zwracał uwagę w doktrynie tamtego okresu F. Longchamps; zob. tegoż, op. cit. s. 91.

48 Dz. Urz. MRiRR Nr 1, poz. 3.

49 Dz. Urz. MRiRR Nr 4, poz. 60.

50 Por. też Instrukcję Komitetu Centralnego Polskiej Partii Robotniczej z dnia 25 października $1944 \mathrm{r}$. przeciwko wypaczeniom w podziale ziemi obszarniczej, opublikowaną [w:] Reforma rolna PKWN..., s. 59-60. Z informacji tam zawartych wynika, że z parcelacji korzystali przede wszystkim robotnicy rolni kosztem chłopstwa. 
Jak stanowi art. 10 ust. 2 dekretu z 6 września 1944 r., pierwszeństwo do skorzystania z reformy rolnej przysługiwało żołnierzom Wojska Polskiego, inwalidom wojennym oraz uczestnikom partyzanckich walk o Polskę demokratyczną. $\mathrm{W}$ uzupełnieniu postanowień tego przepisu, rozporządzenie z 1 marca $1945 \mathrm{r}$. $\mathrm{w} \$ 22$ ust. 2 rozciągało ów przywilej również na wdowy i sieroty po żołnierzach Wojska Polskiego i uczestnikach walk o Polskę demokratyczną ${ }^{51}$. To uprzywilejowane niezależne było od tego, do jakiej grupy (bezrolny, małorolny itp.) uprawnionych do uczestnictwa $\mathrm{w}$ podziale ziemi należała dana osoba. Jednakże nie było ono w sposób należyty honorowane $\mathrm{w}$ toku przeprowadzania parcelacji ${ }^{52}$.

Własność gruntów nadawana była uprawnionym odpłatnie, jednak suma, do uiszczenia której zobowiązani byli nabywcy ustalona była na relatywnie niskim poziomie. Zgodnie z art. 14 ust. 1 dekretu z 6 września 1944 r. cena była równa przeciętnemu rocznemu urodzajowi, który określano na 15 q żyta z 1 ha ziemi trzeciej klasy ${ }^{53}$. Nabywcy mieli obowiązek wpłacić $10 \%$ ceny przy objęciu działek. Pozostałą część ceny małorolni i średniorolni mieli spłacić w ciągu 10 lat, zaś bezrolni w ciągu 20 lat (art. 14 ust. 2). Poszczególne raty płatne były do 10 grudnia każdego roku bez oprocentowania ${ }^{54}$.

Procedura prowadząca do nabycia własności gruntów rolnych przez wymienione kategorie uprawnionych przebiegała $\mathrm{w}$ kilku fazach ${ }^{55}$. Po ustaleniu wyłączeń od podziału (zob. art. 15 dekretu z 6 września 1944 r., $\$ 44$ i 45 rozporządzenia z 1 marca 1945 r.) następowało ustalenie uprawnionych do skorzystania $\mathrm{z}$ reformy rolnej (art. 9 dekretu). Ziemia przeznaczona do parcelacji dzielona była pomiędzy poszczególne gromady ( $\$ 19$ rozporządzenia). Dla każdej z dzielonych nieruchomości sporządzany był projekt podziału ziemi ( $\$ 22$ ust. 1 i $\$ 23$ rozporządzenia). Zarazem sporządzany był spis uprawnionych do uczestnictwa w podziale ziemi danego majątku ( $\$ 21$ rozporządzenia), a równolegle - projekt podziału inwentarza ( $\$ 22$ ust. 1 rozporządzenia). Obydwa projekty rozpatrywane były na ogólnym zebraniu uprawnionych do korzystania z reformy rolnej ( $\$ 27$ rozporządzenia). Projekt podziału ziemi

51 Pomijam w tym miejscu zagadnienie, czy wskazując w rozporządzeniu nową kategorię uprzywilejowanych pierwszeństwem nie przekroczono zakresu upoważnienia do wydania rozporządzenia.

52 Por. pismo okólne Ministra Rolnictwa i Reform Rolnych z 17 maja 1947 r. w sprawie załatwiania spraw inwalidów wojennych, partyzantów, zdemobilizowanych i rodzin po poległych żołnierzach, Dz. Urz. MRiRR Nr 6, poz. 60.

53 Szczegółowe zasady klasyfikacji i oszacowania gruntów zawierała instrukcja Ministra Rolnictwa i Reform Rolnych z 12 grudnia 1946 r. w sprawie ustalenia ceny sprzedażnej nieruchomości ziemskich i ich przynależności dla nabywców z mocy dekretu z 6 września 1944 r. o przeprowadzeniu reformy rolnej (Dz. U. R.P. Nr 3 poz. 13 z 1945 r.), Dz. Urz. MRiRR z 1947 r. Nr 1, poz. 7. Załącznik $\mathrm{nr} 2$ do instrukcji zawierał zasady ustalania ceny sprzedażnej gruntów rolnych w metrach żyta.

54 Zob. $\$ 3$ zarządzenia Ministra Rolnictwa i Reform Rolnych z 23 listopada 1946 r. w sprawie spłat należności Państwowego Funduszu Ziemi, Dz. Urz. MRiRR z 1947 r. Nr 1, poz. 5.

55 Szczegółowo: F. Longchamps, op. cit., s. 60 i nast. 
podlegał zatwierdzeniu przez uprawniony organ ( $\$ 29$ rozporządzenia $)^{56}$. Następnie dokonywano faktycznego podziału ziemi, czyli wydzielenia działek na gruncie, po dokonaniu którego nabywcy byli wprowadzani w posiadanie ziemi i wręczano im akt nadania ziemi i inwentarza ( $\$ 33$ ust. 1 rozporządzenia in fine). Według opisanych już zasad dokonywano ustalania ceny za nabywane grunty. Na podstawie sporządzonego protokołu z czynności klasyfikacji i oszacowania działek oraz inwentarza ( $\$ 37$ ust. 1 rozporządzenia) wydawano decyzje $\mathrm{w}$ przedmiocie klasyfikacji i szacunku, publikowaną poprzez wywieszenie w lokalu zarządu gminy na 7 dni, po upływie którego decyzję uznawało się za doręczoną wszystkim stronom i osobom zainteresowanym ( $\$ 38$ oraz $\$ 39$ rozporządzenia). Prawo własności działki nadanej w toku reformy rolnej wpisywane było w księdze wieczystej na podstawie dokumentu nadania oraz odpisu wykonalnej decyzji w przedmiocie klasyfikacji i szacunku działki łącznie z oszacowaniem przydzielonego nabywcy inwentarza (art. 2 ust. 2 dekretu z 8 sierpnia 1946 r. o wpisywaniu w księgach hipotecznych /gruntowych/ prawa własności nieruchomości przejętych na cele reformy rolnej ${ }^{57}$ ). Jednocześnie jako ciężar realny wpisywano należności z tytułu nie zapłaconej ceny działki i inwentarza (art. 2 ust. 2 dekretu z 8 sierpnia 1946 r. $)^{58}$.

Akt nadania ziemi to decyzja administracyjna przenosząca własność parcelowanej nieruchomości na nabywcę. Chwilą przejścia własności był moment otrzymania aktu nadania ${ }^{59}$. W doktrynie okresu PRL podnoszono, że przyjęta w dekrecie z 6 września 1944 r. konstrukcja nabycia własności wyłączała jakiekolwiek roszczenia względem nowonabywcy podnoszone przez osoby trzecie, w tym przez właściciela pozbawionego władania ${ }^{60}$. Między osobą wyzutą z własności a otrzymującą akt nadania nie istniał, według tej koncepcji, żaden stosunek prawny, natomiast między państwem a nowonabywcami istniał stosunek publicznoprawny ${ }^{61}$. To stanowisko doktryny zostało ukształtowa-

56 Zgodnie z przepisami rozporządzenia wykonawczego był to pełnomocnik powiatowy do spraw reformy rolnej. Pełnomocnicy do spraw reformy rolnej zostali odwołani nieopublikowanym zarządzeniem Ministra Rolnictwa i Reform Rolnych z 21 sierpnia 1945 r., a zakres ich właściwości ostatecznie przeszedł na powiatowe komisje ziemskie (por. dekret z 15 sierpnia 1946 r. o organizacji komisji ziemskich; Dz. U. Nr 61, poz. 340); zob. F. Longchamps, op. cit., s. 39 i nast.

57 Dz. U. Nr 39, poz. 233, z późn. zm.

58 Por. J. Wasilkowski, Zarys prawa rzeczowego, Warszawa 1963, s. 230; M. Świtka, Spłata ciężaru realnego jako należności Skarbu Państwa, „Nieruchomości” C.H. Beck 2006, nr 5, s. 9-11.

59 H. Świątkowski, op. cit., s. 61; jak też okólnik Ministra Rolnictwa i Reform Rolnych z 30 stycznia 1946 r. w sprawie przeciwdziałania nieobsiewaniu gruntów z parcelacji, otrzymanych przez nowonabywców zasiewów oraz naruszeń art. 13 dekretu o przeprowadzeniu reformy rolnej, Dz. Urz. MRiRR Nr 4, poz. 58.

60 J. Paliwoda, op. cit., s. 126-127.

61 Ibidem; zob. również uwagi B. Wierzbowskiego sformułowane w Glosie do wyroku Naczelnego Sądu Administracyjnego z dnia 2 września 1994 r., II SA 2486/9 i II SA 500/94, OSP 1995, nr 6, poz. 126, s. $169-170$. 
ne pod wpływem treści okólnika nr 41 Ministra Sprawiedliwości z 7 sierpnia 1945 r. adresowanego do sądów apelacyjnych, okręgowych i grodzkich w sprawie zakazu odbierania chłopom ziemi nadanej w reformie rolnej ${ }^{62}$. Był on reakcją na fakt, że właściciele bezprawnie pozbawieni władania nieruchomościami występowali do sądów z roszczeniami windykacyjnymi, a te nieraz uznawały racje powodów. O tym, że sądy nie mogą rozstrzygać spraw z zakresu objętego zasięgiem przepisów dekretu z 6 września 1944 r. rozstrzygnął Sąd Najwyższy w uchwale składu siedmiu sędziów z 13 października 1951 r. ${ }^{63}$, której teza brzmiała: „Sąd powszechny nie jest powołany do rozstrzygania o tym, czy $\mathrm{w}$ razie uchylenia w trybie art. 101 postępowania administracyjnego (Dz. U. R. P. z 1928 r. Nr 36, poz. 341) jako nieważnej decyzji władzy administracyjnej, uznającej, że nieruchomość ziemska jest wyłączona spod działania przepisów o reformie rolnej, zostają zachowane prawa rzeczowe osób trzecich, które prawa te wywodzą z czynności właściciela nieruchomości dokonanych przed uchyleniem pomienionej decyzji" ${ }^{64}$.

\subsection{Nadawanie gruntów na Ziemiach Odzyskanych}

Jak wcześniej wspomniano, przed wejściem w życie dekretu z 6 września 1946 r. na Ziemiach Odzyskanych stosowano bez żadnych szczególnych modyfikacji przepisy dekretu z 6 września 1944 r. Procedura prowadząca do uzyskania prawa własności nieruchomości wyznaczona przez ostatni wymieniony akt normatywny była bardziej złożona niż ta ukształtowana dla potrzeb przeprowadzenia reformy rolnej.

62 Reforma rolna PKWN..., s. 182 i nast. H. Świątkowski, uzasadniając poprawność przyjętej w okólniku argumentacji podkreślał m.in., że beneficjenci reformy rolnej nie mają obowiązku badania stosunków własnościowych w odniesieniu do parcelowanych gruntów. Chłopi, obejmując nadane im działki gruntu pozostają zawsze w dobrej wierze, a ta, w połączeniu z aktem nadania ziemi „,czyni własność chłopa niewzruszoną i wyklucza jakiekolwiek roszczenia ze strony osób trzecich"; zob. tegoż, Wykładnia prawno-społeczna (uwagi na tle okólnika w sprawie reformy rolnej), „Demokratyczny Przegląd Prawniczy” 1945, nr 1, s. 21. Oczywiście nie trzeba szczegółowo uzasadniać, że taka argumentacja, w znacznej mierze oparta na przesłankach ideologicznych, nie może zostać uznana w dzisiejszych realiach za przekonującą.

63 C 427/51, OSNCK 1953, nr 1, poz. 1. Uchwale nadano moc zasady prawnej.

64 Należy wspomnieć, że współcześnie Sąd Najwyższy wyraził w wyroku z 13 lutego 2003 r. (opubl. [w:] „Rejent” 2004, nr 8, s. 183-188) opinię, że „odebranie władztwa poprzednim właścicielom w trybie wykonywania przepisów dekretu o reformie rolnej nie wyklucza (...) w wyjątkowych wypadkach udzielenia im lub ich następcom ochrony w procesie windykacyjnym, jeśli okazałoby się, że nieruchomość została odebrana wbrew przepisom dekretu lub nie została następnie rozdysponowana zgodnie $\mathrm{z}$ celami wymienionymi $\mathrm{w}$ art. 1 ust. 2 dekretu i po przejęciu przez państwo nie stała się własnością innych osób fizycznych lub prawnych". W uzasadnieniu stwierdził jednak wyraźnie, że na pozwanych w sprawie cywilnej przeciwko Skarbowi Państwa o wydanie nieruchomości spoczywa ciężar wykazania decyzją administracyjną przewidzianą w $\$ 5$ rozporządzenia z 1 marca 1945 r., iż sporna nieruchomość podpada pod działanie przepisów art. 2 ust. 1 lit. e) dekretu z 6 września $1944 \mathrm{r}$. 
Powierzchnia użytków rolnych $\mathrm{w}$ gospodarstwach nadawanych $\mathrm{w}$ trybie dekretu z 6 września 1946 r. powinna mieścić się w granicach od 7 do 15 ha (art. 9 zdanie pierwsze). Trzeba zauważyć, że wskazane normy obszarowe pojawiły się jeszcze przed wejściem w życie tego dekretu w treści okólnika Ministra Ziem Odzyskanych nr 82 z 15 lipca 1946 r. w sprawie akcji osadniczej na gospodarstwach rolnych $^{65}$. Z wytycznych Ministra Ziem Odzyskanych z 30 stycznia 1947 r. w sprawie czynności związanych z wydawaniem aktów nadania na obszarze Ziem Odzyskanych i b. Wolnego Miasta Gdańska $^{66} \mathrm{w} \$ 10$ wynikało, że $\mathrm{w}$ ramach norm przewidzianych przez dekret, obszar gospodarstw powinien być uzależniony zarówno od jakości gleby, jak i od miejscowych stosunków gospodarczych, w szczególności należało wziąć pod uwagę nasilenie osadnictwa i jego tendencje oraz przewidywania dla danej wsi. Zasadnicze $\mathrm{w}$ tej materii rozporządzenie z 22 listopada $1947 \mathrm{r}^{67}$, $\mathrm{w} \$ 2$ ust. 1 uzależniało wielkość gospodarstw w ramach norm określonych w dekrecie od jakości gruntów, na których były one zlokalizowane. Dla gospodarstw położonych na gruntach I klasy szacunkowej granice obszarowe ustalono na 7 do 9 ha, II klasy od 9 do 12 ha, zaś dla III klasy - 12 do 15 ha $^{68}$. Obszar gospodarstw w ramach wskazanych grup miał być konkretyzowany przy uwzględnieniu miejscowych warunków ekonomicznych (jak stopień uprzemysłowienia, odległość od rynku zbytu, stacji, kolei itp.), terenowych i klimatycznych. Istniejące gospodarstwa o obszarze mniejszym niż 7 ha mogły być nadawane w do-

65 Dz. Urz. MZO Nr 7, poz. 114. Okólnik został wydany w celu ustalenia zasad postępowania przygotowujących wdrożenie w życie postanowień projektowanego jeszcze dekretu, dotyczącego osadnictwa na Ziemiach Odzyskanych, a sam regulował jedynie, jak głosiły jego wstępne postanowienia, „stosunki faktycznego posiadania”. Rozważając jego praktyczną doniosłość (pomimo braku waloru aktu prawa powszechnie obowiązującego) trzeba również mieć na uwadze, że zgodnie z pismem okólnym Ministra Ziem Odzyskanych z 30 lipca 1946 r. w sprawie stosowania zasad dekretu o ustroju rolnym i osadnictwie na Ziemiach Odzyskanych (Dz. Urz. MZO Nr 8, poz. 150), wobec uchwalenia przez Radę Ministrów tegoż dekretu, do czasu uchwalenia stosownych przepisów wykonawczych normujących szczegóły akcji osadniczej, okólnik z 15 lipca 1946 r. należało traktować jako oficjalny komentarz ministerstwa do wspomnianego dekretu.

66 Dz. Urz. MZO Nr 4, poz. 66.

67 Rozporządzenie Ministrów: Rolnictwa i Reform Rolnych, Ziem Odzyskanych oraz Administracji Publicznej z 22 listopada 1947 r. wydane w porozumieniu z Ministrami Obrony Narodowej i Skarbu w sprawie norm obszarowych, szacunku, odliczenia od ceny na rzecz osadników wojskowych oraz spłaty należności za gospodarstwa, nadane na podstawie dekretu z 6 września $1946 \mathrm{r}$. o ustroju rolnym i osadnictwie na obszarze Ziem Odzyskanych i b. Wolnego Miasta Gdańska, Dz. U Nr 74, poz. 471 z późn. zm.

68 Zgodnie z $\$ 2$ ust. 2 rozporządzenia, do I klasy szacunkowej zalicza się grunty I i II klasy gleboznawczej, do II klasy szacunkowej - grunty III i IV klasy gleboznawczej, do III klasy szacunkowej - grunty V i VI klasy gleboznawczej. Podział gruntów na klasy gleboznawcze dokonywany był według tabeli klas gruntów, stanowiącej załącznik do rozporządzenia. Został on uchylony przez $\$ 12$ ust. 1 rozporządzenia Rady Ministrów z 4 czerwca 1956 r. w sprawie klasyfikacji gruntów (Dz. U. Nr 19, poz. 97). 
tychczasowym rozmiarze, przy czym formułowano tu nieprzewidziany wprost $\mathrm{w}$ przepisach dekretu ani wydanych na jego podstawie przepisach wykonawczych wymóg żywotności ${ }^{69}$. Również przywołane wytyczne z 30 stycznia $1947 \mathrm{r}$. w $\$ 11$ uznawały, że gospodarstwa o takim obszarze mogą być utrzymane w dotychczasowym rozmiarze przy spełnieniu tego warunku. Co do wskazanych granic obszarowych dekret dopuszczał pewne odstępstwa. I tak, górna norma obszarowa dla gospodarstw hodowlanych, przez które rozumiano gospodarstwa, w których obszar pastwisk przekracza 30\% ogólnego obszaru gospodarstwa (Sust. 1 rozporządzenia) został wyznaczony na pułapie 20 ha (art. 9, zdanie drugie). Z kolei obszar gospodarstw ogrodniczych nie mógł przekraczać 5 ha (art. 10). Jedynie wyróżnione kategorie gospodarstw ogrodniczych - szkółkarskie i nasienne mogły mieć powierzchnię do 20 ha. Należy przy tym wskazać, że prawodawca ani $\mathrm{w}$ treści dekretu, ani w aktach wykonawczych nie zdefiniował pojęcia "gospodarstwa ogrodniczego". Wiadomo, że w jego ramach mieszczą się wspomniane gospodarstwa szkółkarskie oraz nasienne. Co należy rozumieć pod pojęciem gospodarstw ogrodniczych precyzował okólnik nr 83 Ministra Ziem Odzyskanych z 21 sierpnia 1946 r. „Akcja osadnicza na gospodarstwach rolnych. Gospodarstwa ogrodnicze na Ziemiach Odzyskanych"70, który stanowił: „Pod gospodarstwami ogrodniczymi rozumie się gospodarstwa warzywnicze, sadownicze, szkółkarskie, kwiaciarskie i nasienne, produkujące artykuły ogrodnicze na zbyt i mające przewagę upraw ogrodniczych nad innymi"71. Najniższe pułapy obszarowe wyznaczono dla użytków rolnych wchodzących w skład działek dla osadników rybackich, rzemieślników wiejskich oraz innych działek pracowniczych - odpowiednio 3 ha, 2 ha i 1 ha. Szczegółowe zasady związane z ustalaniem działek wspomnianych rodzajów zawierały wytyczne z 30 stycznia 1947 r. $(\$ \$ 15-17)$.

Dekret z 6 września 1946 r. wskazywał kilka kategorii podmiotów uprawnionych do otrzymania gospodarstw (działek). Należy tu wymienić: po pierwsze, obywateli polskich, którzy przybyli na obszar Ziem Odzyskanych i byłego Wolnego Miasta Gdańska w ramach akcji osiedleńczej, kierowanej przez władze państwowe bądź posiadających grunty rolne za zgodą władz państwowych (art. 14 ust. 1); po drugie, osoby stale zamieszkałe przed dniem 1 stycznia 1945 r. na obszarze Ziem Odzyskanych, które uzyskały lub uzyskają obywatelstwo polskie (art. 14 ust. 2). Nabywcy gospodarstw (działek) musieli spełnić warunki przewidziane $\mathrm{w}$ art. 15 ust. 2, tj. powinni wykazać, że albo mają praktyczne przygotowanie do prowadzenia gospodarstwa rolnego (ogrodnicze-

69 F. Longchamps, op. cit., s. 96; por. też $\$ 11$ wytycznych z 30 stycznia 1947 r.

70 Dz. Urz. MZO Nr 9, poz. 159.

71 Nie można pomijać praktycznej roli wskazanej definicji, zwłaszcza że ten okólnik został wydany jako rozwinięcie okólnika z 15 lipca 1946 r.; por. przypis 55. 
go $)^{72}$ oraz że praca na roli stanowi ich główny zawód, albo że posiadają fachowe wykształcenie rolnicze. Nie dotyczyły one niepełnoletnich, którymi mogły być, przykładowo, osoby osierocone przez żołnierzy ${ }^{73}$. Przesłanką negatywną dyskwalifikującą daną osobę jako potencjalnego nabywcę gospodarstwa (działki) było skazanie jej prawomocnym wyrokiem za występek, polegający na uchylaniu się od służby wojskowej, za zbrodnię lub zbrodnię wojskową oraz skazanie prawomocnym wyrokiem za występek przewidziany w art. 38 lub 39 dekretu z 6 września $1946 \mathrm{r}^{74}$ Uprzywilejowanymi poprzez przyznanie pierwszeństwa do otrzymania konkretnego gospodarstwa (działki) były rodziny nabywców zmarłych przed orzeczeniem o wykonaniu aktu nadania (jeśli nabywca zmarł po otrzymaniu aktu nadania - art. 27, zdanie drugie), a także osoby, które zostały wprowadzone przez władze państwowe w posiadanie gruntów na obszarze Ziem Odzyskanych lub b. Wolnego Miasta Gdańska, (art. 18 ust. 2). Pierwszeństwo niezrelatywizowane do konkretnego gospodarstwa (działki) przysługiwało z kolei zdemobilizowanym żołnierzom i inwalidom Wojska Polskiego, którzy brali udział w walkach o Polskę oraz uczestnikom walk partyzanckich o Polskę $\mathrm{z}$ wyjątkiem tych, którzy występowali przeciwko Polsce Demokratycznej; funkcjonariuszom służby bezpieczeństwa, którzy w związku ze służbą w obronie demokratycznych zasad ustroju Państwa Polskiego zostali inwalidami; wdowom i sierotom po żołnierzach i uczestnikach walk partyzanckich poległych $\mathrm{w}$ walkach o Polskę, jak też wdowom i sierotom po funkcjonariuszach służby bezpieczeństwa, którzy polegli w związku ze służbą w obronie demokratycznych zasad ustroju Państwa Polskiego, oraz osobom, których jedynymi żywicielami byli wymienieni żołnierze; uczestnikom walk partyzanckich i funkcjonariuszom służby bezpieczeństwa; repatriantom; właścicielom gospodarstw małorolnych i karłowatych, znajdujących się na obszarach Państwa Polskiego poza obszarem Ziem Odzyskanych i b. Wolnego Miasta Gdańska.

Dekret z 6 września 1946 r. przyjął złożoną, kilkuetapową procedurę prowadzącą do uzyskania własności gospodarstwa (działki). Dzieliła się ona na trzy fa$\mathrm{zy}^{75}$, powiązane z następującymi aktami administracyjnymi: po pierwsze, orze-

72 Warto wspomnieć, że zarządzenie Ministra Ziem Odzyskanych w porozumieniu z Ministrem Rolnictwa i Reform Rolnych z 27 sierpnia 1946 r. w sprawie przeprowadzenia czynności przygotowawczych do uregulowania prawa własności w osadnictwie rolnym na obszarze Ziem Odzyskanych (Dz. Urz. MZO Nr 9, poz. 157) w $\$ 7$ ust. 2 stanowiło: „Jako praktyczne przygotowanie do prowadzenia gospodarstwa rolnego Komisja Osadnictwa Rolnego może uznać osobistą bezpośrednią pracę fizyczną osadnika na gospodarstwie przez okres co najmniej roku z dodatnim wynikiem".

73 F. Longchamps, op. cit., s. 99.

74 Art. 16 dekretu z 6 września 1946 r. przewidujący wymienione konsekwencje został uchylony na mocy postanowienia art. VII pkt 5 ustawy z 19 kwietnia 1969 r. Przepisy wprowadzające ustawę Kodeks karny (Dz. U. Nr 13, poz. 95 z późn. zm.).

75 Tak, przede wszystkim, F. Longchamps, op. cit., s. 104, tak też konsekwentnie H. Świątkowski (zob. przykładowo tegoż: Niektóre zagadnienia z zakresu uporządkowania i zakończenia reformy rolnej i osadnictwa rolnego, PUG 1958, nr 9, s. 168; Prawo rolne..., s. 51); w najnowszej literaturze: 
czeniem określonym jako akt nadania; po drugie, orzeczeniem o ustaleniu ceny nabycia i po trzecie, orzeczeniem o wykonaniu aktu nadania.

Akt nadania, zgodnie $\mathrm{z}$ art. 25 ust. 1, nie przenosił własności gospodarstwa (działki) na osadnika, lecz wyznaczał jego nabywcę. Przedmiotem aktów nadania mogły być działki fizycznie wydzielone albo też jeszcze niewydzielone. $\mathrm{W}$ tym ostatnim przypadku, jak stanowił art. 25 ust. 2, akt nadania powinien wskazywać nieruchomość, z której grunty przynależne do gospodarstwa (działki) mają być wydzielone, $\mathrm{z}$ określeniem, jakiemu obszarowi przeciętnej jakości gruntów wchodzących w skład tej nieruchomości, odpowiadać ma rozmiar nadanego gospodarstwa (działki). Osoby, które otrzymały akty nadania gospodarstw (działek), fizycznie jeszcze niewydzielonych z większej nieruchomości, miały prawo do prowizorycznego przyznania im całości lub części tej nieruchomości we wspólne posiadanie (art. 26 ust. 1). Grunty oddane we wspólne posiadanie tym osobom mogły być prowizorycznie między nie podzielone w stosunku do obszaru wskazanego w poszczególnych aktach nadania. Otrzymujący akty nadania mieli prawo do posiadania gospodarstw (działek), korzystania z nich i pobierania bezpłatnie pożytków. Uprawnienia te były niezbywalne i niedziedziczne. Oczywistą konsekwencją powyższych uwag jest stwierdzenie, że na podstawie aktu nadania nabywało się prawo podmiotowe, którego komponentami były wymienione wcześniej uprawnienia ${ }^{76}$. Akt nadania jednocześnie nakładał na osadnika obowiązek osobistego prowadzenia gospodarstwa przy pomocy członków rodziny żyjących z nim we wspólnocie gospodarczej, a sankcją za jego niedotrzymanie było cofnięcie aktu nadania (art. 27). Osoba, która otrzymała akt nadania, mogła - do czasu wydania orzeczenia o jego wykonaniu - zrzec się nadanego jej gospodarstwa (działki), z obowiązkiem przekazania go właściwej władzy administracji ogólnej jako władzy ziemskiej (art. 29). Z opisa-

A. Suchoń, P. Kowalczyk, Analiza przepisów dekretu PKWN z 6 września 1944 r. o przeprowadzeniu reformy rolnej wraz z późniejszymi zmianami oraz innych aktów prawnych, na podstawie których nastąpiło przejęcie nieruchomości ziemskich i lasów, [w:] Reformy rolne w Polsce międzywojennej i powojennej. Prawo - realizacja - skutki - problemy reprywatyzacyjne, red. E. Borkowska-Bagieńska, W. Szafrański, Poznań 2008, s. 120-121. W piśmiennictwie wyrażono również pogląd, że procedura prowadząca do nabycia własności przez osadników ma charakter dwufazowy - W. Pawlak, op. cit., s. 51, który odstępując od zajętego we wcześniejszych publikacjach stanowiska odwoływał się do argumentacji przedstawionej przez M. Zimmermanna.

76 Por. uzasadnienie wyroku Sądu Najwyższego z 24 lutego 2004 r., II CSK 135/05, opubl. OSNC 2006, nr 11, poz. 192, gdzie dokonując analizy sytuacji prawnej podmiotu otrzymującego akt nadania, sąd określił, że mamy do czynienia z majątkowym prawem podmiotowym innym niż własność. F. Longchamps twierdził, że w skład wiązki uprawnień, których źródłem był akt nadania wchodzi również roszczenie o przeniesienie własności; tenże, op. cit., s. 108; też: A. Suchoń, M. Kowalczyk, op. cit., s. 120; por. też: A. Stelmachowski, op. cit., s. 42, który pisze o uzyskaniu ekspektatywy prawa własności. We wcześniejszych wypowiedziach ów autor używał sformułowania „prawo uzyskania własności w przyszłości”; tenże, [w:] A. Stelmachowski, B. Zdziennicki, Prawo rolne, Warszawa 1980, s. 52. 
nymi obowiązkami ściśle związane były postanowienia przepisów karnych - odpowiedzialności podlegały czyny takie, jak opuszczenie gospodarstwa (działki) po otrzymaniu aktu nadania i objęciu tego gospodarstwa w posiadanie, nie przekazawszy właściwej władzy (art. 38) ${ }^{77}$, a także obniżanie przez osadnika wartości i zdolności produkcyjnej gospodarstwa (działki), z którego korzysta wykonując uprawnienia wynikające $\mathrm{z}$ aktu nadania, przewidziane w art. 26 (art. 39) ${ }^{78}$.

Gospodarstwa (działki) nabywane były przez osadników odpłatnie. Cena gospodarstwa (działki) ustalana była w drodze orzeczenia o ustaleniu ceny gospodarstwa (działki) jeszcze przed przeniesieniem jego własności na osadnika (art. 30). Świadczenie osadników z tytułu nabycia własności ustalane było na podstawie szacunku składników majątkowych określonych w dekrecie i przepisach wykonawczych. Szacunek gruntów ustalany był w wysokości równej przeciętnemu rocznemu urodzajowi z danego obszaru ziemi, przy czym jako przeciętny urodzaj dla gruntów średniej jakości przyjmowano 15 cetnarów metrycznych żyta z jednego hektara (art. 21 ust. 2) ${ }^{79}$. Osadnikom wojskowym, korzystającym $\mathrm{z}$ pierwszeństwa przewidzianego $\mathrm{w}$ art. 18 ust. 1 pkt 1, odliczano od ceny przypadającej za gospodarstwo (działkę) równowartość gospodarstwa o obszarze 10 hektarów użytków rolnych średniej jakości (art. 22, zdanie pierwsze). Pojęcie osadnika wojskowego obejmowało inwalidów, zdemobilizowanych żołnierzy oraz uczestników walk partyzanckich z Niemcami i ich sprzymierzeńcami (o ile nie występowali oni przeciwko Polsce Demokratycznej) ${ }^{80}$. Według

77 Przepis ten utracił moc obowiązującą z chwilą wejścia w życie dekretu z 6 września $1951 \mathrm{r}$. o ochronie i uregulowaniu własności osadniczych gospodarstw chłopskich na obszarze Ziem Odzyskanych (Dz. U. Nr 46, poz. 340), gdyż z dniem ogłoszenia tego dekretu (7 września 1951 r.) wszyscy użytkownicy tych gospodarstw stali się ich właścicielami z mocy prawa na podstawie art. 2 ust. 1 tegoż dekretu - tak Sąd Najwyższy w postanowieniu z 2 lutego 1956 r., II KO 4/55, OSNCK $1956 \mathrm{nr}$ 3, poz. 42.

78 Zgodnie z okólnikiem Ministra Ziem Odzyskanych z 22 grudnia 1948 r. w sprawie stosowania sankcji karnych przewidzianych w art. 38 i 39 dekretu z 6 września 1946 r. [...], Dz. Urz. MZO Nr 29, poz. 253, obniżenie wartości i zdolności produkcyjnej następowało, gdy użytkownik przestawał być z własnej winy dobrym gospodarzem, np. sprzedawał bez uzasadnienia inwentarz poniemiecki, powodował niszczenie budynków przez nienaprawianie dachów albo w inny sposób wykazywał rażąca niedbałość gospodarczą. Zarówno przepis art. 39 jak i art. 38 zostały uchylone z dniem 1 stycznia 1970 r. przez art. VII pkt 5 ustawy z 19 kwietnia 1969 r. Przepisy wprowadzające ustawę Kodeks karny (Dz. U. Nr 13, poz. 95)

79 Szczegółowe zasady szacunku składników majątkowych, których własność nabywali osadnicy ustanowiło rozporządzenie z 22 listopada 1947 r. w $\$ \$ 8-34$.

80 Powyższe kategorie podmiotów wraz z ich szczegółowymi charakterystykami wprowadzone zostały przez zarządzenie Ministra Ziem Odzyskanych wydane w porozumieniu z Ministrem Obrony Narodowej i Ministrem Administracji Publicznej z 14 stycznia 1948 r. w sprawie określenia pojęcia osadnika wojskowego w akcji osiedleńczej na obszarze Ziem Odzyskanych i byłego Wolnego Miasta Gdańska (Dz. Urz. MZO Nr 3, poz. 17). Wcześniej pojęcie osadnika wojskowego precyzował pkt 7 lit. a) - c) zarządzenia Ministra Ziem Odzyskanych w porozumieniu z Ministrem Administracji Publicznej z 30 stycznia 1947 r. w sprawie powołania Komisji Osadnictwa Rolnego (Dz. Urz. MZO $\mathrm{Nr} 4$, poz. 66). Postanowienia zarządzenia z 30 stycznia 1947 r. straciły moc w zakresie, w jakim były 
art. 23 ust. 1 osobom, które w związku z wojną rozpoczętą we wrześniu 1939 r. utraciły gospodarstwa rolne na terenach Rzeczypospolitej Polskiej w jej granicach przedwojennych, które nie weszły w skład powojennego obszaru państwa, o ile osoby te stale zamieszkiwały na tych terenach przed dniem 1 września 1939 r., jak również osobom, które na mocy umów międzynarodowych, zawartych przez Państwo Polskie, miały otrzymać ekwiwalent w zamian za mienie pozostawione za granicą - zarachowywano na pokrycie ceny nabycia gospodarstwa (działki) wartość utraconego (pozostawionego) gospodarstwa. Jednakże brak odpowiednich przepisów wykonawczych spowodował, że kwestia ekwiwalentów nie posiadała odpowiedniej regulacji ${ }^{81}$.

Własność gospodarstw (działek) uprawnieni otrzymywali na podstawie orzeczenia o wykonaniu aktu nadania (art. 31 ust. 1). W jego treści (art. 31 ust. 2) wymieniano akt nadania, osobę nabywcy oraz przedmiot i warunki nabycia gospodarstwa (działki). Prawo własności nieruchomości uzyskane na podstawie wymienionego aktu wpisywano do księgi wieczystej, jednocześnie wpisując jako ciężar realny należność z tytułu niezapłaconej ceny gospodarstwa (działki) ${ }^{82}$. Pomimo ustawowego obowiązku, władze administracji ogólnej nie wydawały orzeczeń o wykonaniu aktów nadania wszystkim uprawnionym z tytułu aktu nadania. W związku z tym wydany został dekret z 6 września 1951 r. o ochronie i uregulowaniu własności osadniczych gospodarstw chłopskich na obszarze Ziem Odzyskanych ${ }^{83}$. Jak stanowił art. 2 ust. 1, osoby, które posiadają gospodarstwa rolne i prowadzą je osobiście lub przez członków rodziny, żyjących z nimi we wspólności gospodarczej, a do dnia wejścia w życie niniejszego dekretu nie nabyły ich własności, stawały się z mocy prawa właścicielami tych gospodarstw. Dotyczyło to osadników, którzy otrzymali wcześniej akty nadania, jak i tych nielegitymujących się wymienionym aktem. Dekret z 6 września 1951 r. przewidywał w art. 5 ust. 1 wydawanie aktów nadania o charakterze deklaratywnym ${ }^{84}$, stwierdzającym nabycie własności gospodarstw. Z kolei orzeczenie o wykonaniu aktu nadania (art. 6 ust. 1) ustalało granice gospodarstwa oraz ich szacunek. Ów ostatni akt przejawiał wyraźnie cechy konstytutywności. Należy zauważyć, że osadnicy nieraz porzucali gospodarstwa poło-

sprzeczne z zarządzeniem z 14 stycznia 1948 r. (pkt 4 zarządzenia z 14 stycznia 1948 r.). O problemach związanych z regulacją pozycji osadników wojskowych w następnych latach zob. J. Paliwoda, op. cit., s. 130-131.

81 Co do szczegółów zob. H. Świątkowski, Prawo rolne..., s. 65. Powyższej materii dotyczyły postanowienia dekretu z 18 kwietnia 1955 r. o uwłaszczeniu i o uregulowaniu innych spraw, związanych z reformą rolną i osadnictwem rolnym (tekst jedn. Dz. U. z 1959 r. Nr 14, poz. 78 z późn. zm.) - zob. art. $12-15$.

82 Zob. art. 6 dekretu z 28 października 1947 r. o mocy prawnej ksiąg wieczystych na obszarze Ziem Odzyskanych i b. Wolnego Miasta Gdańska (Dz. U. Nr 66, poz. 410 z późn. zm.).

83 Dz. U. Nr 46, poz. 340 z późn. zm.

84 J. Paliwoda, op. cit., s. 138. 
żone na obszarze Ziem Odzyskanych w związku z brakiem poczucia stabilizacji ich pozycji i obawami, że powrócą tam dawni gospodarze - Niemcy.

\section{Zakończenie}

Prawodawca ukonstytuował $\mathrm{w}$ omawianych tu aktach prawnych administracyjnoprawny model transferu państwowej własności rolniczej, eliminując całkowicie wszelkie przejawy autonomii woli, będące fundamentem regulacji prywatnoprawnej. Charakterystyczny jest radykalizm przyjętych przez prawodawcę rozwiązań, widoczny choćby wtedy, kiedy porównuje się je do postanowień ustawy z 28 grudnia 1925 r. o wykonaniu reformy rolnej ${ }^{85}$. Realizacja postanowień dekretu o przeprowadzeniu reformy rolnej, pomijając niedoskonałości przepisów prawa od strony legislacyjnej była, jak wiadomo, prowadzona z pogwałceniem zasad praworządności i całkowicie podporządkowana realizacji celów władzy. Cele deklarowane w przepisach prawa znajdowały się wyraźnie na dalszym planie ${ }^{86}$.

Mając zaś na uwadze samą metodę regulacji prawnej zbywania państwowej własności rolniczej, prawodawca zaczął korzystać z mechanizmów cywilnoprawnych dopiero w 1958 r., uchwalając ustawę z 12 marca 1958 r. o sprzedaży państwowych nieruchomości rolnych oraz uporządkowaniu niektórych spraw związanych z przeprowadzeniem reformy rolnej i osadnictwa rolnego ${ }^{87}$. Nie mieliśmy tu do czynienia z całkowitą eliminacją elementów administracyjnoprawnych, ale mieszanym, cywilno-administracyjnoprawnym modelem transferu państwowej własności rolniczej, w którym zawarcie umowy przenoszącej własność nieruchomości poprzedzone było wydaniem decyzji ustalającej kandydata na nabywcę. Zerwanie z komponentem administracyjnoprawnym, zapoczątkowane ustawą z 24 lutego 1989 r. o zmianie ustawy o sprzedaży państwowych nieruchomości rolnych oraz uporządkowaniu niektórych spraw związanych z przeprowadzeniem reformy rolnej i osadnictwa rolnego ${ }^{88}$, utrwalone zostało obecnie obowiązującą ustawą z 19 października 1991 r. o gospodarowaniu nieruchomościami rolnymi Skarbu Państwa ${ }^{89}$.

85 Dz. U. z 1926 r. Nr 1, poz. 1 z późn. zm. Krytyczne uwagi dot. różnych regulacji reformy rolnej, w tym dotyczące ustawy z dnia 28 grudnia 1925 r. formułuje M. Drewicz, zob. tegoż: Prawo o wywłaszczeniu ziemian i likwidacji większych majątków ziemskich $w$ Polsce $w$ latach 1919-1952 jako czynnik zmiany społecznej oraz wykaz imienny nieruchomości ziemskich podlegających wykupowi przymusowemu na lata 1926-1939, Warszawa 2007.

86 O instrumentalizacji prawa w procesie realizacji reformy rolnej zob. A. Machnikowska, op. cit., s. 192 i nast.

87 Dz. U. Nr 17, poz 71 z późn. zm.

88 Dz. U. Nr 10, poz. 56.

89 Dz. U. z 2007 r. Nr 231, poz. 1700 z późn. zm. 


\section{Bibliografia}

Bendetson W., Świątkowski H., Rola prawa w umocnieniu sojuszu robotniczo-chłopskiego, [w:] Zagadnienia prawne rolnictwa. Materiały konferencji naukowej 5 - 7 grudnia 1955 r., red. S. Szer, Warszawa 1956.

Bielecki Ł., Nacjonalizacja nieruchomości ziemskich na obszarze południowo-wschodniego pogranicza Polski (część I), „Rejent” 2007, nr 5.

Czechowski P., Korzycka-Iwanow M., Prutis S., Stelmachowski A., Polskie prawo rolne na tle ustawodawstwa Unii Europejskiej, Warszawa 2002.

Drewicz M., Prawo o wywłaszczeniu ziemian i likwidacji większych majątków ziemskich w Polsce w latach 1919-1952 jako czynnik zmiany społecznej oraz wykaz imienny nieruchomości ziemskich podlegajacych wykupowi przymusowemu na lata 1926-1939, Warszawa 2007.

Lichorowicz A., Pojęcie nieruchomości ziemskiej w orzecznictwie Trybunału Konstytucyjnego i Naczelnego Sadu Administracyjnego, [w:] Rozprawy prawnicze. Ksiega pamiątkowa Profesora Maksymiliana Pazdana, Zakamycze, Kraków 2005.

Longchamps F., Prawo agrarne, Warszawa 1949.

Machnikowska A, Prawo własności w Polsce w Latach 1944-1981. Studium historycznoprawne, Gdańsk 2010.

Paliwoda J., Przebudowa ustroju rolnego. Zakres działania administracji rolnej, Warszawa 1964.

Pawlak W., Prawo rolne PRL, Warszawa - Poznań 1980.

Pawlak W., Z zagadnień prawnych reformy rolnej w Polsce Ludowej, „Ruch Prawniczy Ekonomiczny i Socjologiczny” 1958, nr 2.

Reforma rolna PKWN. Materiały i dokumenty, Warszawa 1959.

Stelmachowski A., Zdziennicki B., Prawo rolne, Warszawa 1980.

Suchoń A., Kowalczyk P., Analiza przepisów dekretu PKWN z 6 września 1944 r. o przeprowadzeniu reformy rolnej wraz z późniejszymi zmianami oraz innych aktów prawnych, na podstawie których nastąpiło przejęcie nieruchomości ziemskich i lasów, [w:] Reformy rolne w Polsce międzywojennej i powojennej. Prawo - realizacja - skutki - problemy reprywatyzacyjne, red. E. Borkowska-Bagieńska, W. Szafrański, Poznań 2008.

Świątkowski H., Niektóre zagadnienia z zakresu uporządkowania i zakończenia reformy rolnej i osadnictwa rolnego, PUG 1958, nr 9.

Świątkowski H., Prawo rolne, Warszawa 1966.

Świątkowski H., Wykładnia prawno-społeczna (uwagi na tle okólnika w sprawie reformy rolnej), „Demokratyczny Przegląd Prawniczy” 1945, nr 1.

Świtka M., Spłata ciężaru realnego jako należności Skarbu Państwa, „Nieruchomości C.H. Beck" 2006, nr 5.

Wasilkowski J., Zarys prawa rzeczowego, Warszawa 1963. 
Wierzbowski M., Glosa do wyroku Naczelnego Sądu Administracyjnego z dnia 2 września 1994 r., II SA 2486/9 i II SA 500/94, OSP 1995, nr 6, poz. 126.

Zieliński A., Formy prawne gospodarowania nieruchomościami Państwowego Funduszu Ziemi, Poznań 1980.

Ziembiński Z., Logika praktyczna, Warszawa 2002.

Ziętek W., W sprawie pojęcia nieruchomości ziemskiej, „Rejent” 2008, nr 4. 